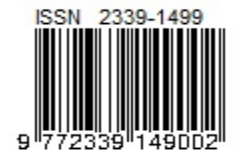

Paper ini telah direview dan dipublikasikan di Jurnal Rekayasa Sistem Industri

Volume 6 No.1 April 2017

http://journal.unpar.ac.id/index.php/jrsi/index

ISSN: 0216-1036 (print) \& ISSN 2339-1499 (online)

\title{
PENGARUH PENCAHAYAAN, POSISI KERJA DAN GENDER TERHADAP PRODUKTIVITAS VISUAL INSPECTION TASK
}

\author{
Yanti Pasmawati ${ }^{1}$, Christofora Desi Kusmindari ${ }^{2}$, Paulus Sukapto ${ }^{3}$, Johanna Renny \\ Octavia $^{4}$ \\ ${ }^{1,2}$ Program Studi Teknik Industri, Fakultas Teknik, Universitas Bina Darma \\ JI. Jend. A. Yani No.03 Plaju, Palembang 30264 \\ Email: yantipasmawati@binadarma.ac.id, desi_christofora@yahoo.com \\ ${ }^{3,4}$ Program Studi Teknik Industri, Fakultas Teknologi Industri, Universitas Katolik Parahyangan \\ Jl. Ciumbuleuit 94, Bandung 40141 \\ Email: paulussukapto@gmail.commailto:johanna@unpar.ac.id
}

\begin{abstract}
Visual inspection task is the inspection activity of a product with the eye position centered over the moving conveyor, the faster the product is produced, the more critical the time of the inspection operator. The conditions in the long term will result in a decrease in productivity (Manuaba, 1992). The research objective to be achieved, among others: (1) Determining the optimal level of productivity based on the studies measure of performance checks on experimental design in every visual inspection task beverage packaging cup "Panther". (2) Determine the influence of lighting, working position and gender on the productivity of visual inspection task on beverage packaging. The object of research is part operator checks on beverage packaging cup "panther". Here are 10 people who have IQ scores of 90-120 aged 20-25 years. The research method was experimental method. The independent variables consist of lighting levels, working position, and gender. Variable manipulated into 12 groups experimental design. Data processing is done by checking the performance measurement approach. Analysis of experimental data using Analysis of Variance (ANOVA), and productivity. The study states that: (1) the highest labor productivity LkB200 experimental design (male, standing working position, the lighting level of 200 Lux) for 0.833. But the productivity of all design experiments have not reached optimal productivity, (2) Areas of different interactions in experimental design factor is the level of lighting in the working position. These factors affect the number of detected defects and work productivity.
\end{abstract}

Keywords: Lighting, Measurement Time, Productivity, Performance Measures Inspection, Analysis of Variance (ANOVA)

\begin{abstract}
ABSTRAK
Visual inspection task merupakan aktivitas inspeksi suatu produk dengan posisi mata terpusat melalui konveyor yang bergerak, semakin cepat produk diproduksi maka semakin kritis waktu dari operator pemeriksaan. Kondisi tersebut dalam jangka waktu lama akan berdampak pada penurunan produktivitas (Manuaba, 1992). Tujuan penelitian yang ingin dicapai, antara lain: (1) Menentukan tingkat produktivitas yang optimal berdasarkan studi ukuran kinerja pemeriksaan pada desain eksperimen di setiap visual inspection task minuman kemasan cup "Panther". (2) Mengetahui pengaruh pencahayaan, posisi kerja dan gender terhadap produktivitas visual inspection task pada minuman kemasan. Objek penelitian adalah operator bagian pemeriksaan pada minuman kemasan cup "panther". Operator berjumlah 10 orang yang memiliki nilai IQ 90-120 yang berusia 20 - 25 tahun. Metode penelitian adalah metode eksperimen. Variabel independen terdiri dari tingkat pencahayaan, posisi kerja, dan gender. Variabel dimanipulasi menjadi 12 kelompok desain eksperimen. Pengolahan data dilakukan dengan pendekatan ukuran kinerja pemeriksaan. Analisis data penelitian menggunakan Analysis of Variance (ANOVA), dan produktivitas. Hasil penelitian menyatakan bahwa: (1) Produktivitas kerja tertinggi yaitu desain eksperimen LkB200 (Laki-laki, posisi kerja berdiri, tingkat pencahayaan 200 Lux) sebesar 0.833. Namun produktivitas semua desain eksperimen belum mencapai produktivitas kerja yang optimal, (2) Faktor interaksi yang berbeda pada desain eksperimen adalah faktor tingkat pencahayaan dengan posisi kerja. Faktor tersebut mempengaruhi jumlah cacat terdeteksi dan produktivitas kerja.
\end{abstract}

Kata kunci: Pencahayaan, Pengukuran Waktu, Produktivitas, Ukuran Kinerja Pemeriksaan, Analysis of Variance (ANOVA) 


\section{PENDAHULUAN}

Visual inspection task merupakan aktivitas deteksi cacat produk, yang disebagian besar industri manufaktur merupakan metode pemeriksaan primer. Produk diperiksa dengan posisi mata terpusat melalui konveyor yang bergerak, semakin cepat produk diproduksi maka semakin kritis waktu dari operator pemeriksaan. Pencarian visual tidak terlalu efektif ketika seorang operator inspeksi mendeteksi benda kecil satu per satu, deteksi diperlukan ketika operator inspeksi memiliki deretan objek untuk diperiksa secara bersamaan (Poulton, 1973).

Aktivitas tersebut perlu memperhatikan faktor pencahayaan, temperatur, dan kebisingan karena dalam jangka waktu lama akan berdampak pada gangguan psikologis seperti kelelahan mata, ketidaknyamanan, dan kehilangan konsentrasi sehingga terjadi penurunan produktivitas, penurunan angka kecelakaan yang berhubungan dengan kerja dan kelelahan (Manuaba, 1992).

Kelelahan kerja merupakan resiko dari dampak faktor sirkadian, faktor pekerjaan, faktor psikologis, dan faktor manusia. Faktor tersebut apabila tidak dikendalikan dengan baik akan berdampak buruk pada produktivitas kerja, kecelakaan kerja dan cidera bagi karyawan atau operator, bahkan kualitas suatu produk. Hal ini terbukti bahwa terdapat 50 juta orang mengalami cidera per tahun akibat pekerjaan, (WHO, 2009; WHO, 2010). Resiko kelelahan kerja juga disebabkan oleh aktivitas kerja yang monoton yang dilakukan secara terus menerus dengan durasi kerja yang relatif panjang, sehingga sangat diperlukan investigasi terkait beban kerja terhadap performansi dalam kondisi monoton (Dunn \& Williamson, 2012).

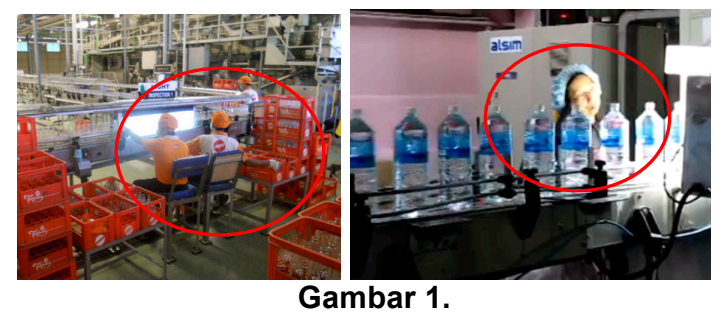

Kondisi Beberapa Work Station Visual Inspection Task di Industri Minuman

Industri minuman kemasan di Indonesia, sebagai salah satu contohnya adalah PT Bumi Pasir Putih merupakan perusahaan yang bergerak di bidang produksi air minum kemasan. Kondisi yang terjadi pada perusahaan sejenis, terdapat beban kerja yang monoton dimana durasi kerja, jumlah jam kerja, lingkungan kerja, dan lingkungan sosial yang terdapat di perusahaan berbedabeda sehingga mempengaruhi tingkat kelelahan kerja yang berbeda pula yang berdampak terhadap produktivitas kerja. Hasil penelitian terdahulu menunjukkan bahwa terdapat pengaruh temperatur dan pencahayaan dalam Ruangan terhadap produktivitas berpikir (kognisi) (Pasmawati, 2014). Hasil penelitian tersebut menyimpulkan bahwa terdapat pengaruh yang signifikan antara desain lingkungan kerja terhadap peningkatan produktivitas dan penurunan beban kerja. Oleh karena itu untuk mencapai produktivitas kerja maka dilakukan rancangan desain eksperimen pada stasiun kerja visual inspection task dengan tujuan penelitian adalah (1) Menentukan tingkat produktivitas yang optimal berdasarkan studi ukuran kinerja pemeriksaan pada desain eksperimen di setiap visual inspection task minuman kemasan cup "Panther". (2) Mengetahui pengaruh pencahayaan, posisi kerja dan gender terhadap produktivitas visual inspection task pada minuman kemasan cup panther.

Objek penelitian adalah visual inspection task pada minuman kemasan cup merk "Panther" untuk mengidentifikasi cacat. Adapun karakteristik atau kategori cacat yaitu volume kurang (Vk), Cup bocor (Cb), Gambar tidak pas (Gtp).

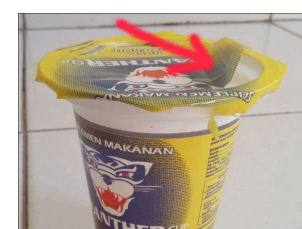

Gambar 2. Cacat Produk Seal Tidak Merekat Sempurna atau Cup Bocor

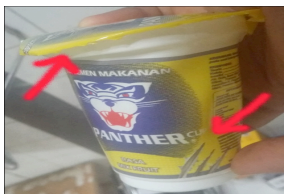

Gambar 3. Cacat Produk Volume Kurang

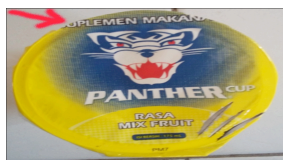

Gambar 4. Cacat Produk Gambar Tidak Pas

Alat dan bahan yang digunakan dalam penelitian ini ialah minuman kemasan Panther Cup, Lampu, Sound level meter, Thermometer, Konveyor, Lux meter, Lembar Pengamatan, Kamera dan Stop Watch. Responden berjumlah 10 orang dengan 
gender laki-laki dan perempuan, nilai IQ 90120 yang terlebih dahulu dilakukan test intelegensi umum (Azwar,2006), waktu pengamatan selama 2.20 jam. Desain eksperimen berjumlah 12 desain eksperimen yang merupakan manipulasi dari variabel independen, seperti yang tergambar pada gambar 5 berikut ini:

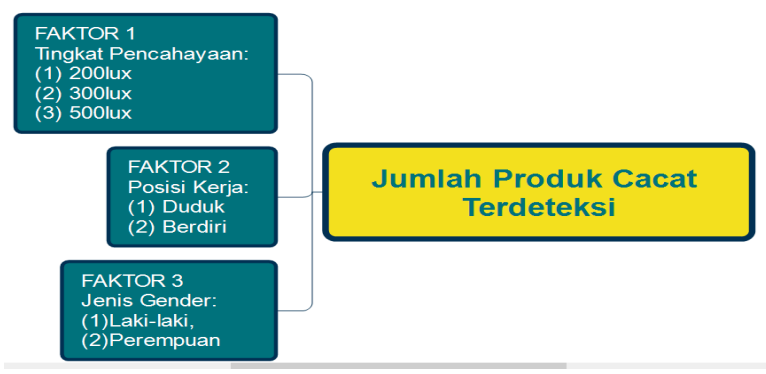

Gambar 5. Kerangka berpikir (variabel independen dan dependen)

Metode penelitian adalah metode eksperimen dengan menggunakan pendekatan ukuran kinerja pemeriksaan. Teknik analisis yang digunakan yaitu analisis tingkat produktivitas dan Analysis of Variance (ANOVA) dalam menyimpulkan hasil penelitian. Agar penelitian sistematis maka dibuatkan flow chart penelitian terdapat pada gambar 6 berikut ini.

\section{HASIL DAN PEMBAHASAN}

Pengendalian kualitas suatu produk sangat penting di dalam suatu proses produksi, hal ini dapat menunjukkan penilaian terhadap kinerja operator atau karyawan yang berdampak penting bagi kinerja perusahaan. Hal tersebut juga diterapkan di visual inspection task untuk minuman kemasan cup merk "Panther".

Langkah-langkah dengan pendekatan Ukuran Kinerja Pemeriksaaan (chengalur dkk, 2004) sebagai berikut:

\section{Persentase Cacat Terdeteksi}

Persentase cacat terdeteksi ini merupakan persentase jumah produk yang terdeteksi menurut operator sesuai karakteristik atau kategori cacat secara keseluruhan dari total jumlah produk cacat. Berdasarkan hasil perhitungan persentase cacat terdeteksi yang terbesar adalah desain eksperimen LkB200 (Laki-laki, posisi kerja berdiri, tingkat pencahayaan 200Lux) sebesar $83.333 \%$. Hal ini menyimpulkan bahwa kinerja pemeriksaan tertinggi terdapat pada desain eksperimen LkB200.

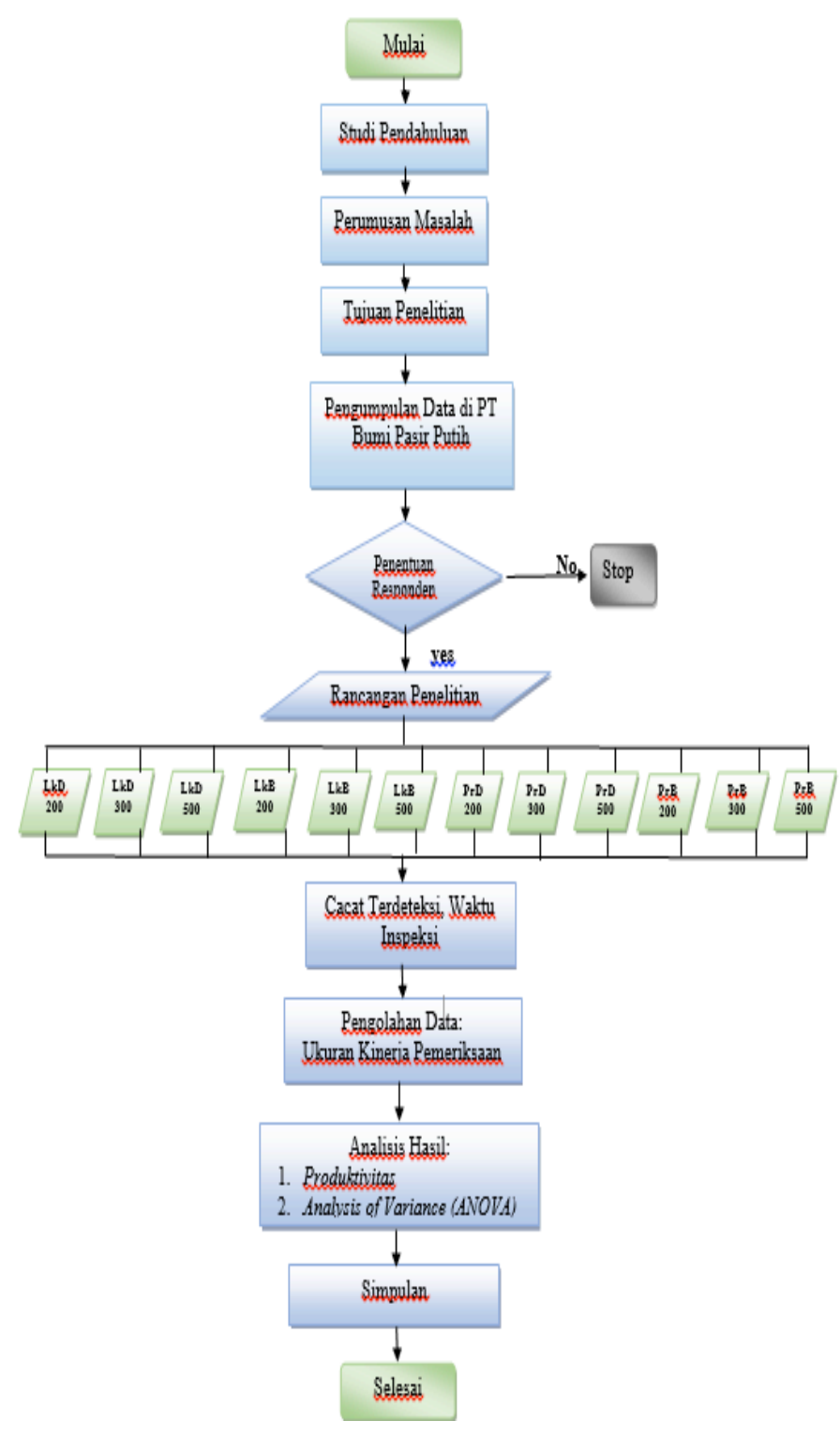

Gambar 6. Flow Chart Penelitian

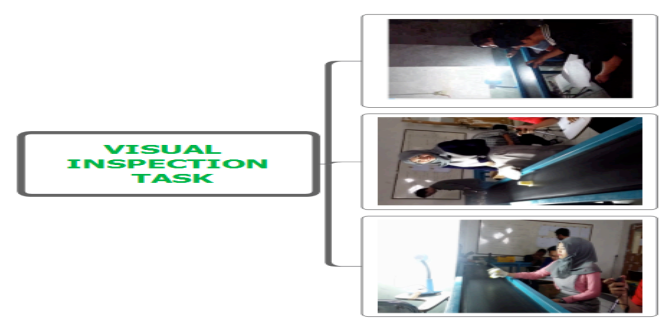

Gambar 7. Visual Inspection Task Pada Minuman Kemasan Panther

\section{Persentase Cacat Dinilai Benar}

Penilaian persentase cacat dinilai benar dilakukan melalui idenfifikasi hasil deteksi cacat oleh operator dengan membuktikan bahwa hasil deteksi tersebut benar dinyatakan cacat berdasarkan karakteristik atau kategori cacat yang ditentukan. Berdasarkan hasil 
perhitungan persentase cacat dinilai benar yang terbesar adalah desain eksperimen LkB200 (Laki-laki, posisi kerja berdiri, tingkat pencahayaan 200 Lux) sebesar $83.333 \%$. Hal ini menyimpulkan bahwa kinerja pemeriksaan tertinggi terdapat pada desain eksperimen LkB200.

\section{Persentase Cacat Dinilai Salah}

Persentase cacat dinilai salah dinyatakan apabila tidak terdapat atau teridentifikasi karakteristik atau kategori produk cacat di produk yang dinyatakan terdeteksi benar oleh operator. Dengan kata lain produk tersebut tidak dinyatakan cacat. Berdasarkan hasil perhitungan persentase cacat dinilai salah, dinyatakan bahwa dari 12 kelompok desain eksperimen tidak terdapat deteksi produk cacat minuman kemasan cup panther yang dilakukan oleh operator adalah salah. Hal ini ditunjukkan dari nilai persentase sebesar $0 \%$ dari ke 12 kelompok desain eksperimen.

Tabel 1. Persentase Cacat Terdeteksi

\begin{tabular}{|c|c|c|c|c|c|c|c|}
\hline DE & JP & JCT & JCTB & $\begin{array}{c}\text { JCTB } \\
(\%)\end{array}$ & $\begin{array}{l}J \\
C \\
S\end{array}$ & $\begin{array}{l}\text { JCS } \\
\text { (\%) }\end{array}$ & JCP \\
\hline $\begin{array}{l}\text { LkB2 } \\
00\end{array}$ & 5040 & 525 & 525 & 83.333 & 0 & 0 & 630 \\
\hline $\begin{array}{l}\text { LkB3 } \\
00\end{array}$ & 5040 & 405 & 405 & 64.286 & 0 & 0 & 630 \\
\hline $\begin{array}{l}\text { LkB5 } \\
00\end{array}$ & 5040 & 488 & 488 & 77.460 & 0 & 0 & 630 \\
\hline $\begin{array}{l}\text { LkD2 } \\
00\end{array}$ & 5040 & 455 & 455 & 72.222 & 0 & 0 & 630 \\
\hline $\begin{array}{l}\text { LkD3 } \\
00\end{array}$ & 5040 & 484 & 484 & 76.825 & 0 & 0 & 630 \\
\hline $\begin{array}{l}\text { LkD5 } \\
00\end{array}$ & 5040 & 466 & 466 & 73.968 & 0 & 0 & 630 \\
\hline $\begin{array}{l}\text { PrB2 } \\
00\end{array}$ & 5040 & 444 & 444 & 70.476 & 0 & 0 & 630 \\
\hline $\begin{array}{l}\text { PrB3 } \\
00\end{array}$ & 5040 & 524 & 524 & 83.175 & 0 & 0 & 630 \\
\hline $\begin{array}{l}\text { PrB5 } \\
00\end{array}$ & 5040 & 519 & 519 & 82.381 & 0 & 0 & 630 \\
\hline $\begin{array}{l}\text { PrD2 } \\
00\end{array}$ & 5040 & 414 & 414 & 65.714 & 0 & 0 & 630 \\
\hline $\begin{array}{l}\text { PrD3 } \\
00\end{array}$ & 5040 & 394 & 394 & 62.540 & 0 & 0 & 630 \\
\hline $\begin{array}{l}\text { PrD5 } \\
00\end{array}$ & 5040 & 390 & 390 & 61.905 & 0 & 0 & 630 \\
\hline
\end{tabular}

Sumber: Pengolahan Data

Keterangan:

DE (Desain Eksperimen), JP (Jumlah Minuman Kemasan (Cup)), JCT (Jumlah Cacat Terdeteksi (Cup)), JTCB (Jumlah Cacat Dinilai Benar (Cup)), JCTB (\%) (Jumlah Cacat Terdeteksi dan terdeteksi benar), JCS (Jumlah Cacat Dinilai Salah(Cup)),JCS (\%) (Jumlah Cacat Dinilai Salah), JCP (Total Produk Cacat (Cup)).

\section{Persentase Cacat Dinamai Benar}

Merupakan jumlah persentase produk cacat yang digolongkan berdasarkan jenis karakteristik atau kategori cacat, dalam hal ini terdiri dari 3 kategori cacat, antara lain
Volume kurang (Vk), Cup bocor (Cb), Gambar tidak pas (Gtp).

Berdasarkan hasil pengolahan data nilai persentase cacat dinamai benar atau pengelompokan cacat berdasarkan kategori cacat tersebut di atas, maka kategori cacat tertinggi adalah volume kurang (Vk) sebesar $35.878 \%$.

Tabel 2. Persentase Cacat Dinamai Benar

\begin{tabular}{ccccccc}
\hline & \multicolumn{7}{c}{ Kategori Cacat } \\
\cline { 2 - 7 } DE & Vk & $\begin{array}{c}\text { Vk } \\
(\%)\end{array}$ & Cb & $\begin{array}{c}\text { Cb } \\
(\%)\end{array}$ & Gtp & $\begin{array}{c}\text { Gtp } \\
(\%)\end{array}$ \\
\cline { 2 - 7 } & & & & \\
LkB200 & 187 & 35.619 & 167 & 31.810 & 171 & 32.57 \\
LkB300 & 140 & 34.568 & 127 & 31.358 & 138 & 34.07 \\
LkB500 & 170 & 34.836 & 152 & 31.148 & 163 & 33.40 \\
LkD200 & 154 & 33.846 & 143 & 31.429 & 140 & 30.77 \\
LkD300 & 167 & 34.504 & 163 & 33.678 & 154 & 31.89 \\
LkD500 & 150 & 32.189 & 142 & 30.472 & 164 & 35.19 \\
PrB200 & 177 & 39.865 & 132 & 29.730 & 137 & 30.86 \\
PrB300 & 188 & 35.878 & 173 & 33.015 & 166 & 31.68 \\
PrB500 & 187 & 36.031 & 159 & 30.636 & 173 & 33.33 \\
PrD200 & 130 & 31.401 & 165 & 39.855 & 119 & 28.74 \\
PrD300 & 121 & 30.711 & 132 & 33.503 & 141 & 35.79 \\
PrD500 & 137 & 35.128 & 110 & 28.205 & 143 & 36.67 \\
\hline & & & & & &
\end{tabular}

\section{Limbah Bahan}

Ukuran kinerja pemeriksaan penelitian ini tidak menghitung limah bahan karena tidak berhubungan dengan cacat produk).

\section{Inspeksi Waktu}

Waktu visual inspection task minuman kemasan cup panther adalah 2.20 jam kerja. Pekerjaan dilakukan secara bergantian dengan operator lain.

\section{Jumlah unit Diinspeksi Per Periode Waktu}

Tabel 3. Waktu Inspeksi Per Cup Minuman Kemasan Panther

\begin{tabular}{cccc}
\hline DE & JP & $\begin{array}{c}\text { Jumlah } \\
\text { Waktu } \\
\text { Inspeksi } \\
\text { (detik) }\end{array}$ & $\begin{array}{c}\text { Waktu } \\
\text { Inspeksi } \\
\text { (detik/cup) }\end{array}$ \\
\hline LkB200 & 5040 & 2460 & 0.488095238 \\
LkB300 & 5040 & 2469 & 0.489880952 \\
LkB500 & 5040 & 2501 & 0.496230159 \\
LkD200 & 5040 & 2460 & 0.488095238 \\
LkD300 & 5040 & 2476 & 0.491269841 \\
LkD500 & 5040 & 2431 & 0.48234127 \\
PrB200 & 5040 & 2492 & 0.494444444 \\
PrB300 & 5040 & 2547 & 0.505357143 \\
PrB500 & 5040 & 2482 & 0.492460317 \\
PrD200 & 5040 & 2497 & 0.495436508 \\
PrD300 & 5040 & 2483 & 0.49265873 \\
PrD500 & 5040 & 2497 & 0.495436508 \\
\hline
\end{tabular}


Berdasarkan data waktu inspeksi tersebut di atas, maka dilakukan perhitungan waktu standar untuk mendeteksi 5040 cup selama 2.20 jam waktu kerja di stasiun kerja visual inspection task (Sutalaksana, 2006) sebagai berikut:

- $\quad$ Menghitung Waktu Siklus (Ws)

$$
\begin{aligned}
W s & =\frac{\sum X_{I}}{N} \\
& =\frac{29795}{12} \\
& =2482.916667 \text { detik }
\end{aligned}
$$

- $\quad$ Menghitung Waktu Normal (Wn)

$$
\begin{aligned}
W n & =W s \times P \\
& =2482.916667 \times 1.06 \\
& =2631.891667 \text { detik }
\end{aligned}
$$

- Menghitung Waktu Baku (Wb)

$$
\begin{aligned}
\text { Wb } & =W n(1+a) \\
& =2631.891667(1+0.33) \\
& =3500.415917 \text { detik }
\end{aligned}
$$

Jadi, waktu baku atau waktu standar untuk mendeteksi 5040 cup adalah 3500.415917 detik.

\section{- Output Standart}

$$
\begin{aligned}
\text { Output standart } & =\frac{1}{\text { Waktu Baku }} \\
& =\frac{1}{3500.415917} \\
& =0.00028568 \mathrm{cup} / \text { detik }
\end{aligned}
$$

Jika dilakukan perhitungan untuk waktu pemeriksaan satu cup, maka digunakan rumus sebagai berikut:

Waktu Inspeksi per cup

$$
\begin{aligned}
& =\frac{\text { jumlahwaktubakuinspeksi }}{\text { jumlah produksi keseluruhan }} \\
& =\frac{3500.415917}{5040} \\
& =0.694526968 \text { detik/cup }
\end{aligned}
$$

Dari hasil perhitungan didapat bahwa waktu yang dibutuhkan untuk melakukan inspeksi satu cup minuman kemasan panther adalah 0.694526968 detik.

Berdasarkan pengolahan data dan hasil dengan menggunakan pendekatan ukuran kinerja pemeriksaan, maka dilakukan dua teknik analisis untuk mengetahui kinerja pemeriksaan dari 12 kelompok desain eksperimen yaitu Produktivitas kerja dan Analysis of Variance (ANOVA)

\section{Analisis Produktivitas}

Produktivitas operator pada penelitian ini didesain dengan dipengaruhi oleh faktor gender, posisi kerja, dan tingkat pencahayaan. Faktor usia, tingkat IQ merupakan control dari kualitas non fisik dari operator. Secara umum produktivitas mengandung pengertian perbandingan terbalik antara hasil yang dicapai (output) dengan keseluruhan sumber daya yang digunakan (input). Dalam hal ini produktivitas visual inspection task dapat ditentukan dengan:

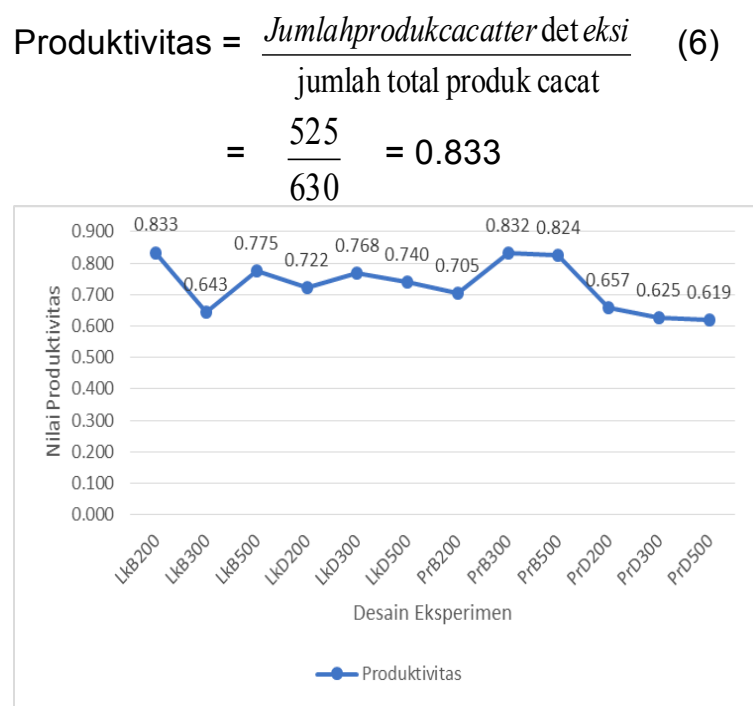

Gambar 8. Produktivitas Dari Visual Inspection Task

Berdasarkan nilai produktivitas tersebut, maka dapat disimpulkan bahwa 12 kelompok desain eksperimen penelitian belum memenuhi batasan standar produktivitas, dimana ditunjukkan dari line yang belum mencapai nilai 1. Namun, dari ke 12 kelompok desain eksperimen, desain eksperimen LkB200 merupakan desain eksperimen yang nilai produktivitasnya tertinggi yairu 0.833 . Oleh karena itu, faktor-faktor tersebut di atas besar artinya bagi penciptaan suasana kerja yang ergonomis, untuk menunjang tercapainya efisiensi di dalam proses yang telah memenuhi batasan standar produktivitas. 


\section{Analysis of Variance (ANOVA)}

Pada tabel levene's test of equality of eror variances, maka:

- $F_{\text {hitung }}$ sebesar 3,384 dengan probabilitas (nilai signifikansi) 0,001 adalah lebih kecil dari 0,05 maka ketiga faktor tersebut tidak memiliki varian yang sama.

- Karena $F$ hitung sebesar 0,457 dengan nilai signifikansi 0,634 adalah $>0,05$ maka dikatakan bahwa untuk tiap jenis pencahayaan memiliki rata-rata deteksi cacat yang sama.

- F hitung sebesar 17,640 dengan nilai signifikansi 0,001 adalah < 0,05 maka dikatakan bahwa untuk tiap posisi kerja memiliki rata-rata deteksi cacat yang tidak sama.

- F hitung sebesar 3,683 dengan nilai signifikansi 0,056 adalah > 0,05 maka dikatakan bahwa untuk tiap gender memiliki rata-rata deteksi cacat sama.

Berdasarkan tabel Test of betweensubject effect, maka:

- Dari tabel Test of between-subjects effects $F_{\text {hitung }}$ untuk interaksi pencahayaan dan jenis kelamin adalah 3,308 dengan probabilitas sebesar 0,038 adalah lebih kecil dari 0,05 maka dikatakan bahwa rata-rata deteksi cacat untuk interaksi pencahayaan dan gender adalah minimal ada satu yang tidak sama.

- Dari tabel Test of between-subjects effects $\mathrm{F}_{\text {hitung }}$ untuk interaksi pencahayaan dan gender adalah 1,451 dengan probabilitas sebesar 0,236 adalah lebih besar dari 0,05 maka dikatakan bahwa rata-rata deteksi cacat untuk interaksi pencahayaan dan posisi kerja adalah berbeda.

- Dari tabel Test of between-subjects effects $F_{\text {hitung }}$ untuk interaksi penerangan dan gender adalah 14,734 dengan probabilitas sebesar 0,001 adalah lebih kecil dari 0,05 maka dikatakan bahwa rata-rata deteksi cacat untuk interaksi pencahayaan dan posisi kerja adalah minimal ada satu yang tidak sama.

- Dari tabel Test of between-subjects effects $F_{\text {hitung }}$ untuk interaksi pencahayaan dan gender adalah 9,092 dengan probabilitas sebesar 0,001 adalah lebih kecil dari 0,05 maka dikatakan bahwa rata-rata deteksi cacat untuk interaksi pencahayaan, gender dan posisi kerja secara signifikan ada satu yang tidak sama.
Hasil uji post hoc untuk pencahayaan nilai signifikansi > 0,05 maka tidak ada perbedaan antara tingkat pencahayaan.

Berdasarkan teknik analisis dengan uji ANOVA yang telah dilakukan, maka dapat disimpulkan bahwa untuk melakukan pendeteksian cacat minuman kemasan cup panther tingkat pencahayaan dan gender tidak ada perbedaan sedangkan tingkat pencahayaan dan posisi kerja terdapat perbedaan. Hal ini menunjukkan bahwa faktor interaksi yang berbeda adalah faktor pencahayaan dengan posisi kerja.

\section{KESIMPULAN}

Berdasarkan hasil dan pembahasan, dapat disimpulkan sebagai berikut:

1. Produktivitas kerja tertinggi yaitu desain eksperimen LkB200 (Laki-laki, posisi kerja berdiri, tingkat pencahayaan 200 Lux) sebesar 0.833. Namun produktivitas semua desain eksperimen belum mencapai produktivitas kerja yang optimal.

2. Faktor interaksi yang berbeda pada desain eksperimen adalah faktor tingkat pencahayaan dengan posisi kerja. Faktor tersebut mempengaruhi jumlah cacat terdeteksi dan produktivitas kerja.

\section{DAFTAR PUSTAKA}

Azwar, S.(2006). Pengantar Psikologi Inteligensi. Yogyakarta: Pustaka Pelajar.

Chengalur, N.S., et al.(2004). Kodak's Ergonomic Design For People At Work, (2th ed.).The Eastman Kodak company. Amerika.

Dunn, N. \& Wiliamson, A.(2012). Driving Monotonous Routes in a Train Simulator. The Effect of Task Demand on Driving Performance and Subjective Experience. Ergonomic, Vol.55 (9), pp. 997-1008.

Manuaba, A.(1992). Pengaruh Ergonomi Terhadap Produktivitas. Dalam Seminar Produktivitas Tenaga Kerja, Jakarta.

Pasmawati,Y., Rachmawati.(2013). Pengaruh Desain Lingkungan Fisik Dalam Ruangan Terhadap Produktivitas Berpikir (kognisi). Prodising Seminar Nasional Teknik Industri (SNTI), ISSN. 2338-7122, pp. 5461. 
Poulton, E.C.(1973). The effect of fatigue inspection work. Applied Ergonomics, pp. 73-83. Department of Engineering Production, University of Birmingham. Birmingham.

Sutalaksana Z, Iftikar., Dkk.(2006). Teknik Perancangan Sistem Kerja, (Edisi kedua). ITB: Bandung.

Tarwaka.(2014). Ergonomi industri. Solo: Harapan Press.
Tarwaka.(2014). Ergonomi Industri: DasarDasar Pengetahuan Ergonomi dan Aplikasi Di Tempat Kerja. Surakarta: Harapan Press Surakarta.

WHO. (2009). Global status report on road safety. World Health Organisation:Geneva.

WHO. (2010). Equity, Social Determinants and Public Health Programs. World Health Organisation: Geneva. 
(halaman ini dibiarkan kosong) 